\title{
Physicochemical and functional properties of cowpea protein isolates treated with temperature or high hydrostatic pressure
}

\author{
F. Peyrano ${ }^{\text {a }}$, F. Speroni ${ }^{\text {b,* }}$, M.V. Avanza ${ }^{\text {a }}$ \\ ${ }^{a}$ Facultad de Ciencias Exactas y Naturales y Agrimensura, Universidad Nacional del Nordeste (UNNE) and Consejo Nacional de Investigaciones Científicas y Técnicas (CONICET), \\ Avenida Libertad 5450, 3400 Corrientes, Argentina \\ ${ }^{\mathrm{b}}$ Centro de Investigación y Desarrollo en Criotecnología de Alimentos (CIDCA), Facultad de Ciencias Exactas, UNLP-CCT La Plata, CONICET, 47 y 116,1900 La Plata, Argentina
}

\section{A R T I C L E I N F O}

\section{Article history:}

Received 20 May 2015

Received in revised form 22 October 2015

Accepted 23 October 2015

Available online 2 November 2015

\section{Keywords:}

Legume protein

High hydrostatic pressure treatment

Thermal treatment

Cowpea protein isolate

\begin{abstract}
A B S T R A C T
The effect of thermal (TT, 70 and $90^{\circ} \mathrm{C}$ ) and high hydrostatic pressure (HHPTs, 200, 400 and $600 \mathrm{MPa}$ ) treatments on physicochemical and functional properties of cowpea protein isolates (CPIs) extracted at pH 8.0 (A8) and $\mathrm{pH} 10.0$ (A10) was analyzed. The pH of protein extraction affected some physicochemical properties (surface hydrophobicity (Ho) and denaturation temperature), without affecting the functional properties. Treatments led to the formation of soluble protein aggregates stabilized by disulfide bonds, especially with TT at $90{ }^{\circ} \mathrm{C}$. TT and HHPTs shifted the wavelengths of maximum emission to red and to blue, respectively. All treatments induced unfolding and denaturation. HHPTs was more efficient than TT to enhance gelation and water holding capacities. Interestingly, treated and untreated CPIs exhibited high values of solubility (72-97\%). TT and HHPT induced greater changes in physicochemical and functional properties of A8 than in those of A10. Remarkably, functional properties were improved from the less energetic treatments $\left(70^{\circ} \mathrm{C}, 200 \mathrm{MPa}\right)$.

Industrial relevance: The comparison between treatments (one traditional and one corresponding to an emerging technology) gives information about the possibility of obtaining modified proteins for different functional purposes. The modified cowpea protein isolates may be used in beverages because of high solubility, in desserts because of gel formation capacity and/or as additives in other foodstuff because of improved water holding capacity. This knowledge would increase the added value of a local production currently marketed without processing.
\end{abstract}

(C) 2015 Elsevier Ltd. All rights reserved.

\section{Introduction}

Cowpea (Vigna unguiculata) is a legume that belongs to the Fabaceae family and is commonly known as black-eyed pea, alubia, caupí, tape or frijole. In the Northeast of Argentina cowpeas are frequently produced by small and medium scale farmers for either personal consumption (human or animal) or trade. Cowpeas are also used as green manure, employed in a rotary scheme with other annual crops or in fruit plantations to increase or sustain soil fertility. In previous studies Avanza,

Abbreviations: CPIs, cowpea protein isolate; A8, cowpea protein isolate, protein extraction carried out at $\mathrm{pH} 8.0 ; \mathrm{A} 10$, cowpea protein isolate, protein extraction carried out at pH 10.0; TT, thermal treatments; HHPTs, high hydrostatic pressure treatments; SDS-PAGE, sodium dodecyl sulfate-polyacrylamide gel electrophoresis; MW, molecular weight; 2-ME, 2-mercaptoethanol; FI, fluorescence intensity; $\lambda_{\max }$, maximum emission wavelength; Ho, surface hydrophobicity; ANS, 1,8-aniline-naphthalene-sulfonate; $T_{d}$, denaturation temperature; $\Delta \mathrm{H}$, enthalpy change of transition; $\mathrm{DD}$, degree of protein denaturation; So, solubility; WHC, water holding capacity; $\eta^{*}$, apparent viscosity; LGC, least gelation concentration.

* Corresponding author.

E-mail addresses: feli_peyrano@hotmail.com (F. Peyrano), franciscosperoni@gmail.com (F. Speroni),vavanza@yahoo.es (M.V. Avanza).
Acevedo, Chaves, and Añón (2013) found protein contents ranging from 24.3 to $27.1 \mathrm{~g} / 100 \mathrm{~g}$ (d.b.) for flours of different varieties of cowpea which make it an attractive source of proteins in replacement of animal proteins. Cowpea proteins, as other vegetable ones, are less expensive and their production requires less energy, land and water resources than animal protein production. Thus, the emphasis in vegetable food proteins may also result in ecological benefits.

The use of cowpea as nourishment has been limited due to the beany flavor, the long time needed to cook it, and the presence of certain antinutritional factors (polyphenols, tannins and phytic acid). By isolating the proteins from cowpea flours, the nutritional properties could be preserved and the negative effects of antinutritional factors could be avoided. Cowpea protein isolates (CPIs) can be used as ingredients and supplements. Their value as ingredients in food products is determined by their nutritional characteristics and functional properties. Such properties are influenced by environmental variables such as temperature, $\mathrm{pH}$ and ionic strength during protein isolation and, also, during food processing, manufacturing, storage and preparation (Kinsella \& Melachouris, 1976; Petruccelli \& Añón, 1994; Mwasaru, Muhammad, Bakar, \& Che Man, 1999). 
The CPIs are prepared by alkaline extraction from defatted flour followed by isoelectric precipitation. The protein structure may be modified during extraction; the standard $\mathrm{pH}$ of extraction for storage proteins from different seeds is 8.0 (Horax, Hettiarachchy, Chen, \& Jalaluddin, 2004; Petruccelli \& Añón, 1995). Mwasaru et al. (1999) tested harsh conditions (agitation at $8500 \mathrm{rpm}$, and $\mathrm{pH}$ up to 12.5) of protein extraction and observed protein denaturation as a consequence of those treatments, even at the lowest $\mathrm{pH}$ tested. Therefore, the effects described by Mwasaru et al. (1999) might be due to a combination of shear stress and high $\mathrm{OH}^{-}$concentrations. Moreover, extremely high $\mathrm{pHs}$ induce the formation of lysinoalanine, a toxic cross-linked amino acid. Thus, the relationship between protein quality and processing parameters is worthy of extensive investigation (Rivas, Dench, \& Caygill, 1981).

Thermal treatment (TT), one of the most traditional in food processing, affects the native structure of food proteins (Kinsella \& Melachouris, 1976). Changes in the secondary, tertiary or quaternary structure are usually referred to as denaturation. Thermal denaturation leads to dissociation of proteins into their constituent subunits, to unfolding of their structure, and to exposure of their hydrophobic groups (Privalov, 1979). The association-dissociation and aggregation because of heating have been widely studied in storage proteins from soybean (Petruccelli \& Añón, 1995), oat (Ma \& Harwalkar, 1988), and kidney bean (Tang \& Mab, 2009), among other seeds.

Over the last decades high hydrostatic pressure treatments (HHPTs) have been shown to constitute an adequate option for satisfying the high demand of high quality and minimally processed, free of additives and microbiologically safe foods. The HHPTs can preserve small molecules (vitamins, free amino acids) and significantly modify secondary, tertiary, and quaternary structures, affecting non-covalent bonds (O'Reilly, Kelly, Murphy, \& Beresford, 2001). In particular, HHPTs produces a variable degree of protein denaturation that depends mainly on the applied pressure level and media composition, leading to aggregation and dissociation of polypeptides and modifying their surface hydrophobicity, solubility and other functional properties.

The aim of this study was to analyze the effects of different treatments that may modify the protein structure: one of them during protein isolation, e.g. increase in the $\mathrm{pH}$ during protein extraction, and other procedures applied on CPIs, e.g. TTs and HHPTs. Those effects were evaluated on physicochemical and functional properties of CPIs. The comparison between treatments (one traditional and one corresponding to an emerging technology) gives information about the possibility of obtaining modified proteins for different functional purposes. The knowledge about the effects of treatments on structural properties of CPIs proteins and the consequences in their functionalities may be useful and would increase the added value of a local production currently marketed without processing.

\section{Materials and methods}

\subsection{Material}

Cowpea seed variety Cuarentón was obtained from Estación Experimental El Sombrero-Corrientes (Instituto Nacional de Tecnología Agropecuaria-INTA) (crop 2012). Shrunken, discolored and insectinfested seeds were eliminated. Seeds were sun-dried and stored in a hermetic vessel at $10{ }^{\circ} \mathrm{C}$ until use.

\subsection{Preparation of cowpea protein isolates}

The preparation of CPIs was carried out according to Qi, Hettiarachchy, and Kalapathy (1997)) with slight modifications. Cowpea seeds were ground (Braun KSM2, coffee grinder, Mexico) and passed through an 80 ASTM $(177 \mu \mathrm{m})$. A $10 \mathrm{~g} / 100 \mathrm{~mL}$ suspension of the obtained flour was defatted with hexane for $24 \mathrm{~h}$ at $4{ }^{\circ} \mathrm{C}$ under continuous stirring. After fat extraction, most of the hexane was separated by filtration and the residual hexane was evaporated at room temperature for $24 \mathrm{~h}$. The defatted flour was dispersed in distilled water $(10 \mathrm{~g} /$ $100 \mathrm{~mL}$ ) and $\mathrm{pH}$ was adjusted to 8.0 or 10.0 using $2 \mathrm{~mol} / \mathrm{L} \mathrm{NaOH}$ for protein extraction. The dispersion was stirred for $60 \mathrm{~min}$ at room temperature and then centrifuged at $10,000 \times \mathrm{g}$ for $30 \mathrm{~min}$ at $20^{\circ} \mathrm{C}$. The $\mathrm{pH}$ of supernatants was adjusted to 4.5 and then centrifuged at $10,000 \times \mathrm{g}$ for $20 \mathrm{~min}$ at $5{ }^{\circ} \mathrm{C}$. Proteins were dispersed in distilled water and $\mathrm{pH}$ was adjusted to 7.0 using $2 \mathrm{~mol} / \mathrm{L} \mathrm{NaOH}$. Samples were then freeze-dried, and stored at $4{ }^{\circ} \mathrm{C}$. The protein content of the flour and the CPIs was determined by the Kjeldhal method $(\mathrm{N} \times 6.25)$ (AOAC, Official methods of analysis, 1990). Ash percentage was determined according to AOAC, Official methods of analysis (1990). The CPIs obtained were termed A8 and $\mathrm{A} 10$ according to their $\mathrm{pH}$ of extraction.

\subsection{Protein dispersions and treatments}

Prior to thermal (TT) and high hydrostatic pressure (HHPT) treatments, aqueous dispersions of $\mathrm{A} 8$ and $\mathrm{A} 10$ at $10 \mathrm{mg}$ protein $/ \mathrm{mL}$ $(\mathrm{pH} 7.0)$ were prepared. For TT, the protein dispersions were heated in a water bath at 70 or $90{ }^{\circ} \mathrm{C}$ for $5,10,20$ or $30 \mathrm{~min}$. The time of treatment was recorded once the dispersion reached the desired temperature and it was monitored during all treatment by using a thermocouple $\pm 1{ }^{\circ} \mathrm{C}$ (model Tes-1317R, RTD DATA Logger Thermometer, Taiwan). After heating, dispersions were immediately cooled by immersion in an ice bath. Heating and cooling rates were ca. 50 and $45{ }^{\circ} \mathrm{C} / \mathrm{min}$, respectively. For HHPTs, the protein dispersions were vacuum-conditioned in polyethylene flasks and were subjected to 200,400, or $600 \pm 5 \mathrm{MPa}$ for $5 \mathrm{~min}$ in a High Pressure System Stansted Fluid Power Ltd. model FPG 9400:922 (Stansted, UK) with a vessel working volume of $2 \mathrm{~L}$, equipped with temperature and pressure regulation. A mixture of propylene glycol and water (30:70) was used as compression fluid. The target pressure was reached at $6.5 \mathrm{MPa} / \mathrm{s}$ and released at $20 \mathrm{MPa} / \mathrm{s}$. Conditioning temperature of vessel and initial temperature of compression fluid were $20^{\circ} \mathrm{C}$. The adiabatic heating was manifested as an increase in temperature that was maximal for $600 \mathrm{MPa}$ (maximal temperature $=38^{\circ} \mathrm{C}$ ). The treated $\mathrm{A} 8$ and A10 were freeze-dried and stored at $4{ }^{\circ} \mathrm{C}$ until analysis.

\subsection{Sodium dodecyl sulfate polyacrylamide gel electrophoresis (SDS-PAGE)}

All gels were run in minislabs (Bio-Rad Mini Protean Tetra Cell Model). SDS-PAGE was performed according to Laemmli's (1970) using continuous gels ( $12 \mathrm{~g} / 100 \mathrm{~mL}$ acrylamide). Treated and untreated A8 and A10 were dispersed ( $1 \mathrm{mg} / \mathrm{mL}$ protein ) in $0.125 \mathrm{~mol} / \mathrm{L} \mathrm{Tris-HCl}$, pH 6.8, $20 \mathrm{~mL} / 100 \mathrm{~mL}$ glycerol, $0.1 \mathrm{~g} / 100 \mathrm{~mL}$ SDS, and $0.05 \mathrm{~g} / 100 \mathrm{~mL}$ bromophenol blue and centrifuged at $15,800 \times g$ for 5 min at $4{ }^{\circ} \mathrm{C}$. Supernatants were loaded on to the gel (30-40 $\mu$ g protein per lane). Samples to be run under reducing conditions were boiled for $1 \mathrm{~min}$ in sample buffer containing $5 \mathrm{~mL} / 100 \mathrm{~mL}$ 2-mercaptoethanol (2-ME) before centrifugation. Electrophoresis was performed at a constant current of $30 \mathrm{~mA}$ per gel for approximately $45 \mathrm{~min}$. Molecular weight standards provided by Pharmacia Hepar Inc., (Franklin, OH, USA) were used. Gels were fixed and stained with Coomassie Brilliant Blue dye solution ( $2 \mathrm{~g} / \mathrm{L})$ in water/methanol/acetic acid (5:5:2) overnight and destained with $25 \% v / v$ methanol and $10 \% v / v$ acetic acid. Gels images were acquired with a HP Scanjet G2710 scanner.

\subsection{Fluorescence spectroscopy}

Treated and untreated A8 and A10 were dispersed $(1 \mathrm{mg} / \mathrm{mL}$ protein) in buffer Tris- $\mathrm{HCl} 0.05 \mathrm{~mol} / \mathrm{L} \mathrm{pH} 7.5$ and stirred for $1 \mathrm{~h}$ at room temperature; all dispersions were centrifuged at $10,000 \times \mathrm{g}$ for $30 \mathrm{~min}$ at room temperature, the supernatants were analyzed. The intrinsic fluorescence was determined at $25^{\circ} \mathrm{C}$, with a Perkin-Elmer LS 50B fluorescence spectrophotometer at an excitation wavelength of $280 \mathrm{~nm}$ (slit width, $5 \mathrm{~nm}$ ), an emission wavelength of 300-450 nm (slit width, $5 \mathrm{~nm}$ ), and a scanning speed of $300 \mathrm{~nm} / \mathrm{min}$ (Perkin-Elmer, Waltham, 
MA, USA). Samples at concentrations $0.01 \mathrm{mg} / \mathrm{mL}$ were obtained by dilution of the initial $1 \mathrm{mg} / \mathrm{mL}$ protein dispersion in buffer Tris- $\mathrm{HCl}$ $0.05 \mathrm{~mol} / \mathrm{L} \mathrm{pH} 7.5$. The protein concentration was determined according to Lowry, Rosebrough, Farr, and Randall (1951).

\subsection{Surface hydrophobicity (Ho)}

The parameter Ho of treated and untreated A8 and A10 was determined according to Cardamone and Puri (1992), employing 1,8-aniline-naphthalene-sulfonate (ANS) as fluorescent probe (Aldrich Chemical Co., Milwaukee, Wisconsin, USA). The emission spectra $(370-600 \mathrm{~nm})$ of the sample $(0.020-0.030 \mathrm{mg} / \mathrm{mL}$ protein $)$ equilibrated with different ANS concentrations (from 0.0 to $100 \mu \mathrm{mol} / \mathrm{L}$ ) were first recorded and the fluorescence measurements then corrected by subtracting the corresponding blank (ANS alone solutions at the same concentration as the sample) to obtain the increase in fluorescence as a result of ANS binding $(\Delta F I)$. The $\Delta F I$ at $470 \mathrm{~nm}$ ( $\lambda$ of maximum emission of ANS-protein complex) was finally plotted vs. the ANS concentration $(\mu \mathrm{mol} / \mathrm{L})$ and the data were adjusted with the following equation:

$\Delta F I=\frac{\mathrm{A} \times \mathrm{ANS}}{\mathrm{B}+\mathrm{ANS}}$

where the coefficients are $A=\Delta F I_{\max }\left(\Delta F I_{\max }\right.$ is the fluorescence intensity at saturation) and $\mathrm{B}=1 / \mathrm{Ka}$ ( $\mathrm{Ka}$ is the equilibrium-binding constant, from the fitting). The Ho is proportional to $\Delta F I_{\max }$ per $\mathrm{mg}$ protein and therefore estimated from Eq. 1 by dividing $A$ by the protein concentration of each sample (Lowry et al., 1951).

\subsection{Differential scanning calorimetry (DSC)}

A Perkin-Elmer Pyris-1 differential scanning calorimeter (Waltham, MA, USA) was employed to study the thermal properties of CPIs. Indium was used as standard (melting point $156.6^{\circ} \mathrm{C}$, enthalpy change $28.46 \mathrm{~J} / \mathrm{g}$ ) for temperature and heat flow calibration. Hermetically sealed aluminum pans were prepared to hold $15-20 \mathrm{mg}$ of treated and untreated $A 8$ and $A 10$ suspended in water ( $15 \mathrm{~g} / 100 \mathrm{~g}$ protein). Samples were scanned at $5{ }^{\circ} \mathrm{C} / \mathrm{min}$ from 25 to $105^{\circ} \mathrm{C}$. As a reference, an empty pan was used. The denaturation temperatures $\left(\mathrm{T}_{\mathrm{d}}{ }^{\circ} \mathrm{C}\right)$, and the enthalpy change of transition ( $\Delta \mathrm{H} \mathrm{J} / \mathrm{g}$ dry protein), were obtained by analyzing the thermograms with the OriginPro 8 software (OriginLab Corporation, Northampton, MA, USA).

The degree of protein denaturation (DD) was calculated according to the following equation:

$\mathrm{DD} \%=100-\Delta \mathrm{H}_{\mathrm{t}} / \Delta \mathrm{H}_{0} \times 100$

where $\Delta \mathrm{H}_{\mathrm{o}}$ and $\Delta \mathrm{H}_{\mathrm{t}}$ are the enthalpy changes corresponding to the untreated and treated sample, respectively.

\subsection{Protein solubility (So)}

Protein solubility of treated and untreated A8 and A10 was determined in water $(1 \mathrm{mg} / \mathrm{mL}, \mathrm{pH} 7.0)$ by the method of Bera and Murkherjee (1989). Protein solubility was expressed as the percent ratio between soluble protein in the supernatants determined by Lowry et al. (1951) and total protein content determined by the Kjeldhal's method (AOAC, Official methods of analysis, 1990). Bovine serum albumin was used as standard.

\subsection{Water holding capacity (WHC)}

Treated and untreated $\mathrm{A} 8$ and $\mathrm{A} 10$ were dispersed in water $(\mathrm{pH} 7.0$ ) at $10 \mathrm{~g} / 100 \mathrm{~mL}$ using a vortex mixer and then stirred for $30 \mathrm{~min}$ at room temperature. After the mixture was thoroughly wetted, samples were centrifuged $\left(9000 \times \mathrm{g}, 20 \mathrm{~min}, 20^{\circ} \mathrm{C}\right)$. After centrifugation, the volume of water remaining in the supernatant was recorded. The soluble proteins in the supernatant were also determined according to Lowry et al. (1951). WHC (g water/g sample) was calculated as:

$\mathrm{WHC}=\mathrm{m}_{2}-\left(\mathrm{m}_{1}-\mathrm{m}_{3}\right) / \mathrm{m}_{1} * \delta$

where $m_{1}$ is the weight of the dry sample $(g), m_{2}$ is the weight of the sediment $(\mathrm{g})$, and $\mathrm{m}_{3}$ is the weight of the soluble protein from the supernatant $(\mathrm{g}), \delta$ : water density $(1 \mathrm{~g} / \mathrm{mL})$.

\subsection{Apparent viscosity $\left(\eta^{*}\right)$}

The apparent viscosity of $10 \mathrm{~g} / 100 \mathrm{~mL}$ of treated and untreated A8 and $\mathrm{A} 10$ dispersions in distilled water was measured at $20^{\circ} \mathrm{C}$. Assays were carried out in a HAAKE rheometer (RheoStress 6000 model, Thermo Electron Corporation, Germany, 2004) using a parallel plate sensor (PP35) with a $1 \mathrm{~mm}$ gap and a deformation speed of $500 \mathrm{~s}^{-1}$. Apparent viscosity was reported (cP). Data were analyzed with the RheoWin 3.30 software (2004).

\subsection{Least gelation concentration (LGC)}

The heat-induced gelation of CPIs dispersed in water was determined by the method of Coffmann and García (1977) with slight modifications. A series of concentrations of treated and untreated A8 and A10 dispersions from 6 to $16 \mathrm{~g} / 100 \mathrm{~mL}$ with increments of $2 \mathrm{~g} / 100 \mathrm{~mL}$ were prepared in $1 \mathrm{~mL}$ deionized water. The test tubes containing these dispersions were then heated in a boiling water bath for $30 \mathrm{~min}$ followed by rapid cooling under running cold tap water. The test tubes were further cooled for $4 \mathrm{~h}$ at $4{ }^{\circ} \mathrm{C}$. The LGC of CPIs was determined as the lowest concentration at which the dispersion from the inverted test tube did not slip or spill. The dispersion appearance was visually observed.

\subsection{Statistical analysis}

Both A8 and A10 were prepared 4 times; protein content and yield were calculated by averaging the values of each preparation. Then, the 4 preparations of A8 (or A10) were mixed to perform treatments and analysis. All treatments were performed in triplicate in protein dispersions. Also, all experimental analyses were performed in triplicate. An analysis of variance (ANOVA) of the data was performed and a least significant difference (LSD) test with a confidence interval of $95 \%$ was used to compare the means of treated and untreated samples. The statistical analysis was performed using the Infostat software (Di Rienzo et al., 2008).

\section{Results and discussion}

\subsection{Protein content of samples and protein extractability}

The protein content of defatted cowpea flour was $26 \mathrm{~g} / 100 \mathrm{~g}$ (d.b.). No significant differences were observed between protein content of $\mathrm{A} 8$ and $\mathrm{A} 10(92.39 \pm 1.98$ and $91.48 \pm 2.20 \mathrm{~g} / 100 \mathrm{~g}$ (d.b.), respectively, $\mathrm{p}>0.05)$. Ash percentage was also determined, no significant differences were detected for A8 and A10 (5.24 \pm 0.04 and $5.40 \pm 0.04 \mathrm{~g} / 100 \mathrm{~g}$ (d.b.), respectively, $p>0.05$ ). The values of protein content are in agreement with those reported by other authors (Horax et al., 2004; Mwasaru et al., 1999). The yield of total seed protein extracted was $56 \pm 1$ and $61 \pm$ $2 \mathrm{~g} / 100 \mathrm{~g}$ for $\mathrm{A} 8$ and $\mathrm{A} 10$, respectively $(\mathrm{p}<0.05)$. This increase in the yield was due to the higher solubility of cowpea proteins at $\mathrm{pH} 10.0$ than at pH 8.0 (Avanza, Chaves, Acevedo, \& Añón, 2012). These yields belong to the range reported by Mwasaru et al. (1999)). Protein may have remained in the pellets of centrifugation at $\mathrm{pH} 8$ or 10 (after protein extraction) and/or in the supernatant of centrifugation at pH 4.5 (after isoelectric precipitation), thus protein recovery in CPIs was not complete. 


\subsection{Molecular characterization}

Untreated A8 and A10 resulted in similar electrophoretic patterns; this fact suggests that the increase in $\mathrm{pH}$ of protein extraction modified the amount of extracted protein, but not its polypeptide composition. For each assayed treatment no differences in their effects were detected between electrophoretic patterns of A8 and A10. Because of this, only the A8 patterns are shown in Fig. 1. Under non-reducing conditions, the untreated CPIs presented polypeptides of $80,60,56,52$ and $42 \mathrm{kDa}$. These polypeptides belonged to the $7 \mathrm{~S}$ globulin fraction (Rangel, Domont, Pedrosa, \& Ferreira, 2003). Furthermore, CPIs presented polypeptides of 94, 33-25 and 20-14 kDa, which correspond to albumin fraction (Vasconcelos et al., 2010). No protein aggregates were found in the stacking gel; however, species with molecular weight $(\mathrm{MW})>94 \mathrm{kDa}$ were found in the resolving gel (Fig. 1a, c, and e). Under reducing conditions, the polypeptides of 42,80 and $>94 \mathrm{kDa}$ were not observed; however, an increase in the intensity of the band corresponding to the polypeptide of $20 \mathrm{kDa}$ was found (Fig. 1b, d, and f). These findings indicate the presence of disulfide bonds in such protein species. Avanza et al. (2013) have reported similar results in the electrophoretic patterns of proteins from cowpea flours cultivated in the Northeastern region of Argentina, with the exception of the MW > 94 kDa aggregates, suggesting that such molecular species could have been generated during CPI preparation.

After TT at $70{ }^{\circ} \mathrm{C}$, soluble aggregates appeared, which did not enter, neither the stacking nor the running gel. These aggregates were found to be stabilized by disulfide bonds (Fig. $1 \mathrm{a}$ and $\mathrm{b}$ ). The relative abundance of these aggregates increased with the treatment time. After TT at $90^{\circ} \mathrm{C}$ more aggregates were formed, some of them remained even under reducing conditions, suggesting that interactions other than disulfide bonds could be operating (Fig. 1c and d). The TT, mainly those carried out at $90^{\circ} \mathrm{C}$, provoked the disappearance of the $42 \mathrm{kDa}$ band and a time-dependent decrease in the intensity of the $80 \mathrm{kDa}$ band (Fig. 1a, c and d). These facts suggest that these polypeptides were involved in aggregates of high MW. The formation of protein aggregates induced by the TT has also been observed by other authors: in amaranth protein isolates (Avanza \& Añón, 2007) and in soybean protein isolate (Petruccelli \& Añón, 1995). With HHPTs, after a 200 MPa treatment, aggregates that were stabilized by disulfide bonds and did not enter the resolving gel were formed. After 400 and $600 \mathrm{MPa}$ treatments, aggregates that did not enter the resolving neither the stacking gel (Fig. 1e). The results suggest that the 400 and $600 \mathrm{MPa}$ treatments
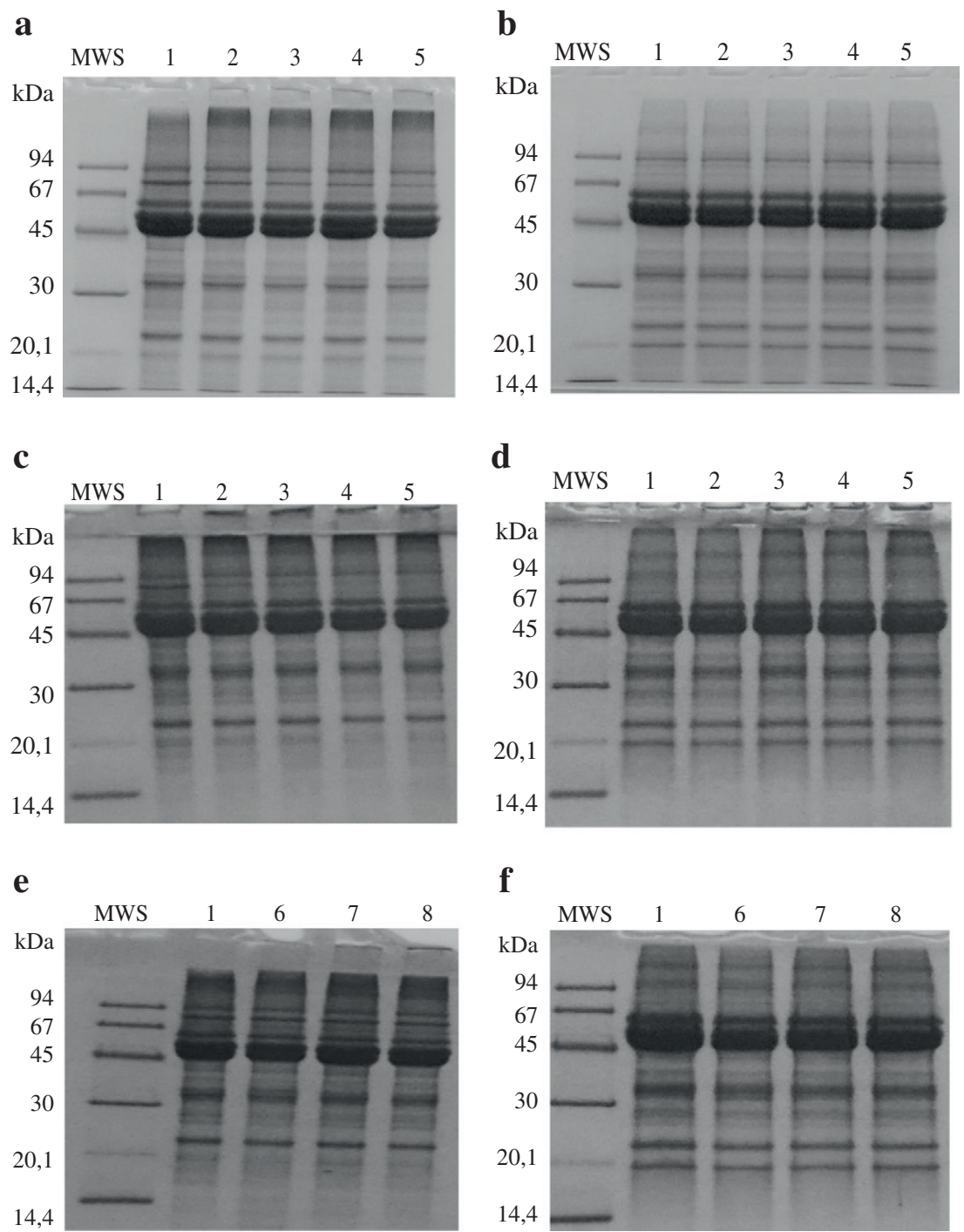

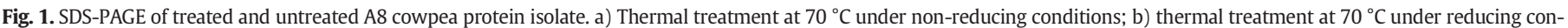

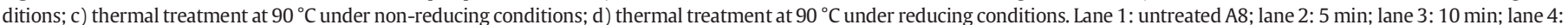

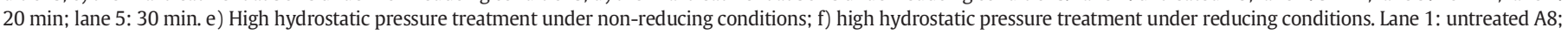
lane 6: $200 \mathrm{MPa}$; lane 7: $400 \mathrm{MPa}$; lane 8: $600 \mathrm{MPa}$. MWS: molecular weight standards. 
were more effective than the $200 \mathrm{MPa}$ ones for producing high MW soluble aggregates. No changes in 80 and $42 \mathrm{kDa}$ were detected after HHPTs, indicating that HHPT-induced aggregates had a different composition compared with TT-induced ones. Protein aggregation induced by HHPTs was also reported by Speroni et al. (2009) in soybean protein isolate and by Condés, Speroni, Mauri, and Añón (2012) in amaranth protein isolate. Our results indicate that the aggregation and dissociation phenomena induced by TTs and HHPTs were different and led to different species, which may behave differentially as functional ingredients.

\subsection{Fluorescence spectroscopy}

Tryptophan (Trp) residues have a maximum emission wavelength in water at $348 \mathrm{~nm}\left(\lambda_{\max }\right)$ and are the dominant intrinsic fluorosphores in proteins. The fluorescence spectrum depends mainly on the polarity of the medium in which Trp is present and gives information on the
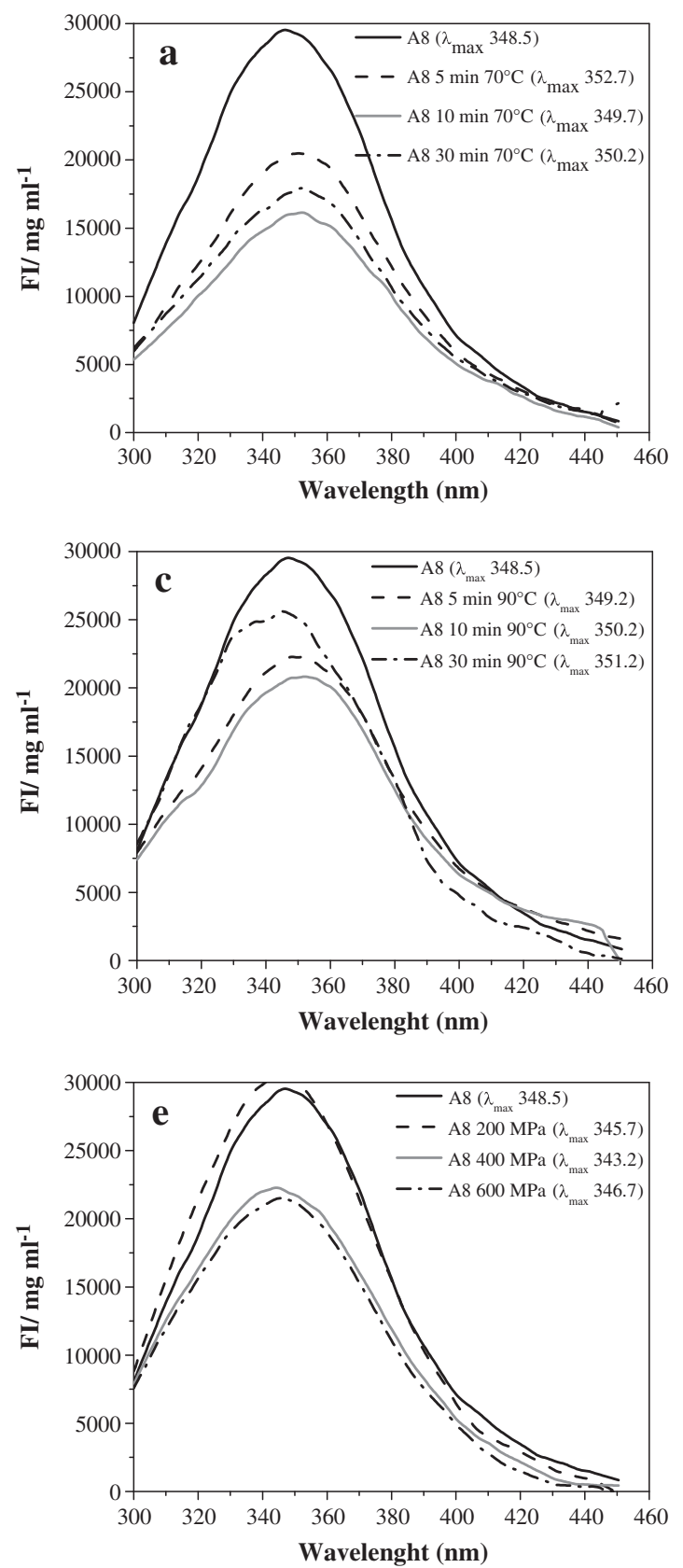

conformational changes of proteins (Lakowicz, 1983). Untreated A8 and A10 presented $\lambda_{\max }$ at $348.5 \pm 0.7 \mathrm{~nm}$ and $344.7 \pm 0.3 \mathrm{~nm}$, respectively ( $\mathrm{p} \leq 0.05$ ) (Fig. 2). These results suggest that the Trp in A10 is surrounded by a more hydrophobic environment. The fluorescence intensity (FI) values were 30,183 \pm 716 and $29,004 \pm 1978 \mathrm{FI} / \mathrm{mg} / \mathrm{mL}$ for A8 and A10, respectively (Fig. 2).

In the A8 isolate, the TTs induced a red shift in the $\lambda_{\max }(p \leq 0.05)$ (Fig. 2a and c). Contrarily, the TTs caused no change in the $\lambda_{\max }$ corresponding to A10 (Fig. 2b and d). Ma and Harwalkar (1988) have reported that the treatment at $110{ }^{\circ} \mathrm{C}$ of the globulin fraction of oats induce a higher degree of exposure of its Trp to a more polar environment. The FI of both isolates decreased significantly after the TT, mainly at $70{ }^{\circ} \mathrm{C}$ (Fig. 2a and b, p < 0.05). On the other hand, the HHPTs treatments on A8 induced a blue shift in the $\lambda_{\max }$, mainly when $400 \mathrm{MPa}$ were applied (Fig. 2e). Contrarily, Yin, Tang, Wen, Yang, and Li (2008) reported a red shift in the $\lambda_{\max }$ in kidney bean protein isolates treated at $600 \mathrm{MPa}$.
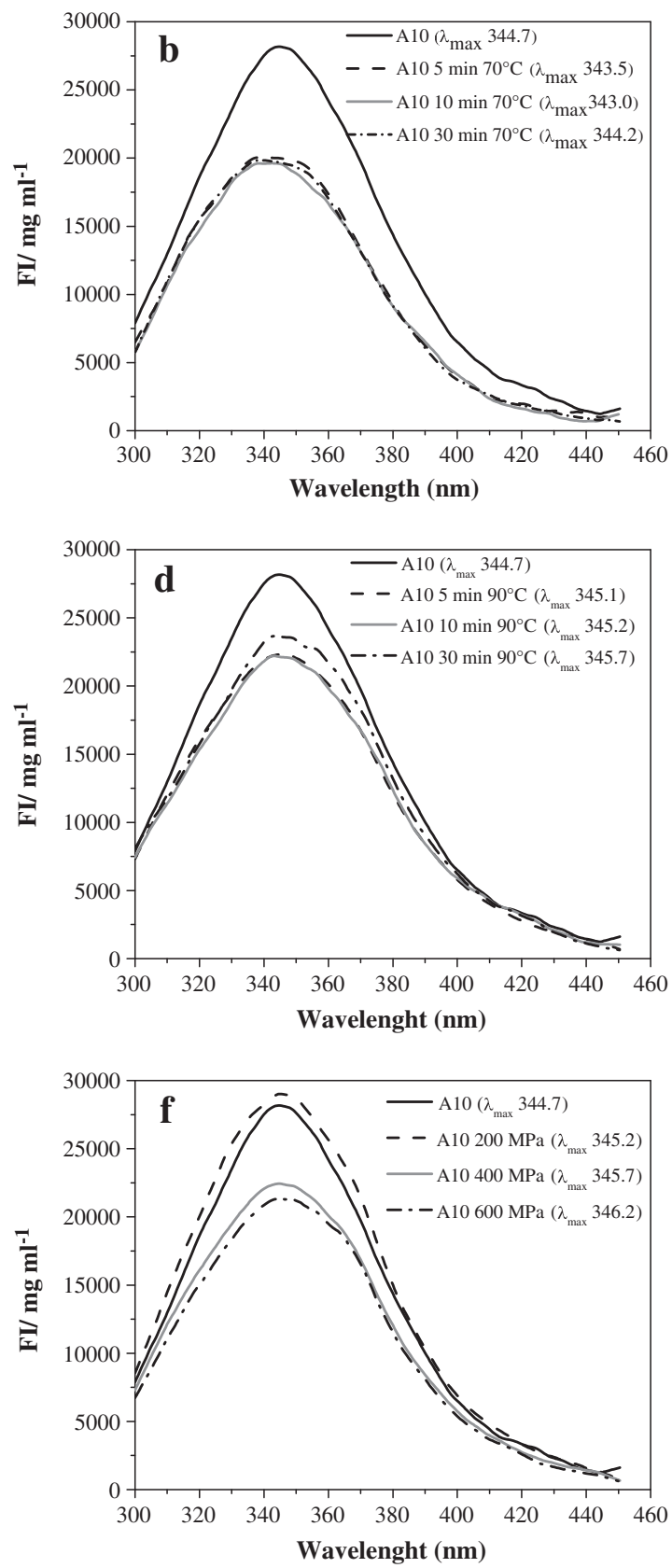

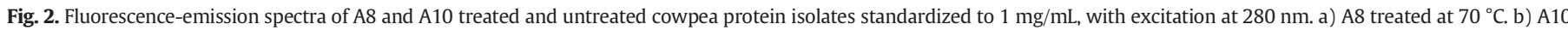
treated at $70{ }^{\circ} \mathrm{C}$. c) A8 treated at $90{ }^{\circ} \mathrm{C}$. d) A10 treated at $90{ }^{\circ} \mathrm{C}$. e) A8 treated with HHP. f) A10 treated with HHP. 
Likewise with the TTs, the HHPTs caused no significant changes in the $\lambda_{\max }$ of the A10 isolate, but a tendency to a red shift (Fig. 2f, p > 0.05). The values of FI of both isolates underwent a significant decrease only with the treatments at 400 and $600 \mathrm{MPa}$ (Fig. 2e and f, p $<0.05$ ), conditions that had provoked a higher degree of aggregation than the $200 \mathrm{MPa}$ treatment (Fig. 1e). Our data indicate that A8 and A10 differently reacted when subjected to the same treatments. A8 was more prone than A10 to undergo conformational changes that affected Trp microenvironment. Possibly, the high $\mathrm{OH}^{-}$concentration during protein extraction has already modified the microenvironment of Trp in A10 toward a more shielded one, thus changing its sensibility to further treatments. These data indicate that TTs and HHPTs provoked the exposure of Trp to different environments with a subsequent fluorescence quenching. Proposed quenching agents from proteins are lysine and histidine residues and disulfide bonds (Lakowicz, 1983; Permyakov, 1993). In our case, the disulfide bonds that stabilized soluble aggregates (Fig. 1) may be responsible for FI decrease.

\subsection{Surface hydrophobicity (Ho)}

The Ho value of A10 was twice that of A8 (Table 1). This fact could be due to irreversible changes during the protein extraction process, such as a differential occurrence of aggregation and/or dissociation. This result is in accordance with those from fluorescence spectroscopy, in which A10 presented lower $\lambda_{\max }$ values than A8, thus demonstrating that the Trp of A10 was immersed in a more apolar environment.

The TTs induced a significant increase $(p<0.05)$ in the Ho values of both isolates (Table 1). The maximum increase in Ho after TT at $70{ }^{\circ} \mathrm{C}$ was greater for $\mathrm{A} 10$ (149\%) than for A8 (36\%). After the TT at $90{ }^{\circ} \mathrm{C}$, the maximum increase in Ho ranged from 74 to $81 \%$ in both isolates. The highest Ho values in A8 were obtained at the shortest times of TTs (Table 1), which suggests that re-arrangements due to prolonged times may occur in $\mathrm{A} 8$ at $70^{\circ} \mathrm{C}$. In the case of $\mathrm{A} 10$, the highest values were obtained at $70^{\circ} \mathrm{C}$, this fact suggests that re-arrangements may occur by increasing temperature to $90{ }^{\circ} \mathrm{C}$. Tang, Sun, and Yin (2009) have observed that Ho could still increase with treatments of $30 \mathrm{~min}$ at $95{ }^{\circ} \mathrm{C}$ in Phaseolus isolates and that at 60 and $120 \mathrm{~min}$ at $95{ }^{\circ} \mathrm{C}$, the Ho value started to decrease, which was attributed to the exposure on non-polar amino acids followed by a rearrangement and aggregation of the polypeptides.

In the case of HHPTs, the maximum increases in Ho were 153 and $22 \%$ for A8 and A10, respectively and no significant differences $(p>0.05)$ were found when the pressure was elevated from 200 to $600 \mathrm{MPa}$ (Table 1). Yin et al. (2008) have reported an increase in the Ho of a Phaseolus vulgaris isolate subjected to HHPTs, in their case the increase was significant for $600 \mathrm{MPa}$ but not for 200 or $400 \mathrm{MPa}$.

Our results show that CPIs may be obtained with Ho values belonging to a wide range (from 1356 to $6754 \mathrm{IF} / \mathrm{mg} / \mathrm{mL}$ protein), by applying different TTs or HHPTs. A8 and A10 exhibited different sensitivity to treatments: Ho of A8 was greatly increased by HHPTs, whereas Ho of A10 was greatly increased by TT at $70{ }^{\circ} \mathrm{C}$.

Table 1

Surface hydrophobicity (Ho $\mathrm{FI} / \mathrm{mg} / \mathrm{mL}$ protein) of treated and untreated A8 and A10 cowpea protein isolates.

\begin{tabular}{lllcl}
\hline & TT $70{ }^{\circ} \mathrm{C}$ & TT $90^{\circ} \mathrm{C}$ & & HHPTs \\
\hline A8 & $1356 \pm 80^{\mathrm{c}}$ & $1356 \pm 80^{\mathrm{c}}$ & A8 & $1356 \pm 80^{\mathrm{b}}$ \\
$5 \mathrm{~min}$ & $1843 \pm 47^{\mathrm{a}}$ & $2263 \pm 40^{\mathrm{ab}}$ & $200 \mathrm{MPa}$ & $3401 \pm 87^{\mathrm{a}}$ \\
$10 \mathrm{~min}$ & $1807 \pm 41^{\mathrm{a}}$ & $2450 \pm 14^{\mathrm{a}}$ & $400 \mathrm{MPa}$ & $3439 \pm 202^{\mathrm{a}}$ \\
$30 \mathrm{~min}$ & $1548 \pm 67^{\mathrm{b}}$ & $2160 \pm 62^{\mathrm{b}}$ & $600 \mathrm{MPa}$ & $3450 \pm 69^{\mathrm{a}}$ \\
A10 & $2708 \pm 178^{\mathrm{c}}$ & $2708 \pm 17^{\mathrm{c}}$ & A10 & $2708 \pm 178^{\mathrm{b}}$ \\
$5 \mathrm{~min}$ & $6140 \pm 183^{\mathrm{b}}$ & $4250 \pm 48^{\mathrm{b}}$ & $200 \mathrm{MPa}$ & $3172 \pm 38^{\mathrm{a}}$ \\
$10 \mathrm{~min}$ & $6745 \pm 166^{\mathrm{a}}$ & $4380 \pm 49^{\mathrm{b}}$ & $400 \mathrm{MPa}$ & $3472 \pm 33^{\mathrm{a}}$ \\
$30 \mathrm{~min}$ & $6764 \pm 150^{\mathrm{a}}$ & $4715 \pm 49^{\mathrm{a}}$ & $600 \mathrm{MPa}$ & $3297 \pm 196^{\mathrm{a}}$ \\
\hline
\end{tabular}

The values are means \pm standard deviation. Different superscripts indicate significant differences $(\mathrm{p}<0.05)$ within columns for each treatment (TT at $70{ }^{\circ} \mathrm{C}$, TT at $90^{\circ} \mathrm{C}$ or HHPT).

\subsection{Thermal behavior}

Both untreated $\mathrm{A} 8$ and $\mathrm{A} 10$ had only one major peak corresponding to $7 \mathrm{~S}$ globulins (Horax et al., 2004). The denaturation temperatures $\left(\mathrm{T}_{\mathrm{d}}\right)$ were $83.96 \pm 0.07{ }^{\circ} \mathrm{C}$ and $84.60 \pm 0.17^{\circ} \mathrm{C}$ for $\mathrm{A} 8$ and $\mathrm{A} 10$, respectively $(\mathrm{p} \leq 0.05)$. These $\mathrm{T}_{\mathrm{d}} \mathrm{s}$ are in the range corresponding to protein denaturation in typical thermograms of cowpea flours (Avanza et al., 2013) and in CPIs (Horax et al., 2004). The higher $\mathrm{T}_{\mathrm{d}}$ of $\mathrm{A} 10$ compared with $\mathrm{A} 8$ may be due to the higher salt content, since more $\mathrm{NaOH}$ was needed to reach $\mathrm{pH} 10$ during protein extraction and more $\mathrm{HCl}$ was needed to neutralize the $\mathrm{OH}^{-}$during protein precipitation. Moreover, protein species with higher thermal stability may have been formed when extraction was carried out at $\mathrm{pH} 10$. The denaturation enthalpies $(\Delta \mathrm{H})$ were $10.49 \pm$ 0.60 and $10.29 \pm 1.17 \mathrm{~J} / \mathrm{g}$ proteins for $\mathrm{A} 8$ and $\mathrm{A} 10$, respectively, without significant differences between them $(p>0.05)$. These $\Delta H$ values are similar to those obtained by Horax et al. (2004) but are higher than those of Mwasaru et al. (1999), who have found a $\Delta H$ of $5.01 \mathrm{~J} / \mathrm{g}$ after an extraction procedure carried out at $\mathrm{pH}$ of 8.5 . These data suggest that the denaturation reported by Mwasaru et al. (1999) might be due to the shear stress caused by vigorous agitation, and probably subsequent heating. Moreover, Mwasaru et al. (1999) have reported decreased $\Delta \mathrm{H}$ with increasing extraction $\mathrm{pH}$. However, in our work no significant differences in $\Delta \mathrm{H}$ were observed between untreated $\mathrm{A} 8$ and $\mathrm{A} 10$, despite differences that were observed in fluorescence spectroscopy, Ho and $\mathrm{T}_{\mathrm{d}}$. Since $\Delta \mathrm{H}$ comes from the balance between endothermic reactions, such as the breakup of hydrogen bonds, and exothermic reactions, such as protein aggregation and the breakup of hydrophobic interactions (Privalov, 1979), similar $\Delta H$ values may represent different protein species that arise from structural changes of CPIs components.

After TTs and HHPTs, a significant decrease in $\Delta H$ was observed in both isolates, indicating protein denaturation ( $p<0.05$ ), in accordance with the changes detected in Ho and fluorescence spectra. The behaviors of both CPIs in terms of DD after TT or HHPTs were similar, without significant differences between A8 and A10, except for TT at $90{ }^{\circ} \mathrm{C}$ where $A 8$ achieved a higher DD than $A 10$. At $70{ }^{\circ} \mathrm{C}$, the time of treatment influenced the DD: for 5 and $30 \mathrm{~min}$ the DD values were $44 \%$ and $75 \%(p \leq 0.05)$, respectively (averages of both CPIs). At $90{ }^{\circ} \mathrm{C}, \mathrm{DD}$ was $78 \%$ and no effect of time of treatment was detected (average of both CPIs and both times, Table 2). Avanza and Añón (2007)) reported for amaranth protein isolate DD of $30 \%$ when heated at $70{ }^{\circ} \mathrm{C}$ and $55-$ $75 \%$ when heated at $90{ }^{\circ} \mathrm{C}$. After HHPTs, the DD depended on pressure level: at $200 \mathrm{MPa}$ DD of $41 \%$ was achieved (average of both CPIs), whereas at 400 and $600 \mathrm{MPa}$ DD of $66 \%$ was achieved (averages of both CPIs and both pressure levels, Table 2). Condés et al. (2012) reported DD of 75 and $95 \%$ at $200 \mathrm{MPa}$ and $600 \mathrm{MPa}$, respectively for amaranth protein isolate. Speroni, Añón \& de Lamballerie (2010) reported DD of 28 and $84 \%$ at $200 \mathrm{MPa}$ and $400 \mathrm{MPa}$, respectively, for soybean protein isolate. These data indicate that the sensitivity to HHPTs-induced

Table 2

Degree denaturation (DD \%) of treated and untreated A8 and A10 cowpea protein isolates.

\begin{tabular}{lll}
\hline & A8 & A10 \\
\hline $\begin{array}{l}\text { TT } 70{ }^{\circ} \mathrm{C} \\
5 \mathrm{~min}\end{array}$ & $40.8 \pm 4.4^{\mathrm{b}}$ & $46.3 \pm 5.3^{\mathrm{b}}$ \\
$30 \mathrm{~min}$ & $75.1 \pm 4.9^{\mathrm{a}}$ & $74.7 \pm 4.3^{\mathrm{a}}$ \\
$T T 90^{\circ} \mathrm{C}$ & & \\
$5 \mathrm{~min}$ & $76.8 \pm 8.6^{\mathrm{a}}$ & $79.4 \pm 3.0^{\mathrm{a}}$ \\
$30 \mathrm{~min}$ & $85.3 \pm 1.1^{\mathrm{a}}$ & $71.9 \pm 4.4^{\mathrm{a}}$ \\
& & \\
HHPTs & & $38.8 \pm 4.2^{\mathrm{b}}$ \\
$200 \mathrm{MPa}$ & $43.7 \pm 7.5^{\mathrm{b}}$ & $58.8 \pm 8.1^{\mathrm{a}}$ \\
$400 \mathrm{MPa}$ & $70.3 \pm 4.7^{\mathrm{a}}$ & $64.6 \pm 4.6^{\mathrm{a}}$ \\
$600 \mathrm{MPa}$ & $69.9 \pm 1.3^{\mathrm{a}}$ & \\
\hline
\end{tabular}

The values are means \pm standard deviation. Different superscripts indicate significant differences $\left(\mathrm{p}<0.05\right.$ ) within columns for each treatment (TT at $70{ }^{\circ} \mathrm{C}$, TT at $90^{\circ} \mathrm{C}$ or HHPTs). 
denaturation of CPIs is smaller than that of amaranth proteins and similar to that of soybean proteins.

\subsection{Protein solubility (so)}

A8 and A10 exhibited high So in water, $91.5 \pm 3.4$ and $93.6 \pm 3.6 \%$, respectively (Table 3 ). These values are within the range informed by Rangel et al. (2003) for CPIs and cowpea purified-vicilins, who worked at a lower protein concentration $(0.5 \mathrm{mg} / \mathrm{mL})$.

After TT at $70{ }^{\circ} \mathrm{C}$, So of A8 decreased as the time of TT increased. The lowest value of So was found after a treatment for $30 \mathrm{~min}$ (72\%). In contrast, for TT at $90{ }^{\circ} \mathrm{C}$, no changes in So were detected except for the longest time, where a slight decrease was observed (So $=85 \%$; $\mathrm{p} \leq 0.05$, Table 3 ). The decrease in So due to TT may be due to the formation of insoluble aggregates, mainly at $70{ }^{\circ} \mathrm{C}$. At $90{ }^{\circ} \mathrm{C}$ the formation of soluble aggregates prevailed, in agreement with the electrophoretic patterns obtained (Fig. 1c). The So from Phaseolus protein isolate has been found to increase after $30 \mathrm{~min}$ and to decrease after $120 \mathrm{~min}$ when samples were treated at $95^{\circ} \mathrm{C}$, (Tang et al., 2009), also suggesting a two-step aggregation behavior. No significant changes in the So of A10 were observed at any time or temperature (Table 3 ). The different behaviors of A8 and A10 towards TT reinforce the idea emerged from fluorescence spectroscopy and Ho, which consisted in the existence of differences in molecular structure of A8 and A10..

After HHPTs, So of A8 and A10 decreased significantly ( $p \leq 0.05)$ at 200 and $400 \mathrm{MPa}$, while at $600 \mathrm{MPa}$ So was similar to that of untreated samples (Table 3). However, in Phaseolus protein isolate, a So increase was found upon treatment with $400 \mathrm{MPa}$ (Yin et al., 2008). Yet, So of water-dispersed soybean protein isolates, has been found to be increased after HHPTs at $600 \mathrm{MPa}$, at pHs between 6.4 and 8.0 (Manassero, Vaudagna, Añón, \& Speroni, 2015). Chapleau and de Lamballerie-Anton (2003) working with Lupinus albus proteins, reported a So of $80 \%$ in samples treated at $600 \mathrm{MPa}$. Taken together, these data suggest that HHPTs leads to highly soluble storage proteins of several vegetable sources.

Despite the changes in So caused by TTs and HHPTs, treated CPIs exhibited higher values when compared with other treated protein isolates such as those of amaranth and soybean (Avanza \& Añón, 2007; Petruccelli \& Añón, 1994).

\subsection{Water holding capacity (WHC)}

The WHC values of untreated A8 and A10 were $1.05 \pm 0.06$ and $0.95 \pm 0.01$ (g water/g sample), respectively; and were not significantly different ( $p>0.05$, Table 3 ). These values were lower than those reported by other authors for CPIs (Khalid, Elhardallou, \& Elkhalifa, 2012; Ragab, Babiker, \& Eltinay, 2004). The differences may be due to the high solubility of A8 and A10, to cultivar differences and/or to sample processing.

The TTs increased WHC at both temperatures in both isolates; the higher values were found after $30 \mathrm{~min}$ of treatment, except for A8 at $90{ }^{\circ} \mathrm{C}$ (Table 3 ). In the case of $\mathrm{A} 8$ after the treatment at $70{ }^{\circ} \mathrm{C}$, the increase in WHC seemed to correlate with the decrease in So (Table 3) and with increase of denaturation degree (Table 2), because these three properties were function of time. The effect of HHPTs on WHC of A8 was an increase at $200 \mathrm{MPa}$ but a decrease at $600 \mathrm{MPa}$ (Table 3). The decrease in WHC of A8 after 600 MPa may be due to an important structural modification, reflected as changes in the surface of proteins, with a high Ho (Table 1) and Trp residues in a more hydrophobic environment (Fig. 2e), accompanied by a $70 \%$ degree of denaturation (Table 2). On the other hand, HHPTs produced an important increase on WHC in A10 that was proportional to pressure level. This increase in WHC of A10 may be related with the tendency to a red shift observed in $\lambda_{\max }$, which suggested a more polar environment of Trp residues (Fig. 2f). The WHC increase may be due to unfolding-induced exposure of polar amino acids. Petruccelli and Añón (1994) obtained a higher increment in WHC when soybean protein isolates were subjected to TT at higher protein concentration, thus having a higher degree of aggregation and a lower solubility. In our case a correlation between changes in So and WHC was not observed, obtaining CPIs with high So and increased WHC. The same behavior was reported by Bernardino-Nicanor, Añón, Scilingo, and Dávila-Ortiz (2005) for guava seed glutelins.

\subsection{Apparent viscosity $\left(\eta^{*}\right)$}

The untreated A8 and A10 dispersions had similar $\eta^{*}$ values (5.75 \pm 0.03-5.97 $\pm 0.35 \mathrm{cP}$ ) (Fig. 3). After the TTs on A8 there was a tendency to increase $\eta^{*}$, that in the case of $70{ }^{\circ} \mathrm{C}$ may be related to the decrease in solubility, reflected as a more particulate system. Moreover, the increase in $\eta^{*}$ may be due to the increase in the molecular size due to the TTinduced aggregation detected by SDS-PAGE (Fig. 1). Ragab et al. (2004) have reported that heating a CPIs at $70{ }^{\circ} \mathrm{C}$ for 15 min resulted in an appreciable increase in viscosity when a higher concentration was assayed $(20 \mathrm{~g} / 100 \mathrm{~mL})$. On the other hand, the HHPTs significantly decreased $\eta^{*}$ of both A8 and A10 (Fig. 3, p $<0.05$ ). Such decrease in the $\eta^{*}$ may be caused by irreversible modifications on protein structure but it also may be due to the breakdown of the aggregates which are stabilized by weak interactions during viscosity determination (Condés et al., 2012). The different behavior of $\eta^{*}$ after TTs and HHPTs could be related to the different aggregation pattern (higher amount of high-molecular weight species in TT- than in HHPT-treated samples) as observed in SDS-PAGE assays (Fig. 1). On the other hand, the low protein concentration $(1 \mathrm{~g} / 100 \mathrm{~mL})$ employed during TT and HHPTs could be the cause of the slight changes observed in this functional property. Condés et al. (2012) have reported that protein concentration modulates the effects of HHPTs and also found no differences between the $\eta^{*}$ values of untreated and treated $(1 \mathrm{~g} / 100 \mathrm{~mL})$ amaranth proteins..

\subsection{Least gelation concentration (LGC)}

The LGC indicates the gelation capacity, the lower the LGC the better is the gelling ability of proteins. The untreated A8 and A10 showed a good gelling capacity (12\%) (Table 4), such capacity is in line with the

Table 3

Protein solubility (So \%) and water holding capacity (WHC g water/g sample) of treated and untreated A8 and A10 cowpea protein isolates.

\begin{tabular}{|c|c|c|c|c|c|c|c|}
\hline & \multicolumn{2}{|l|}{ TT $70{ }^{\circ} \mathrm{C}$} & \multicolumn{2}{|l|}{ TT $90{ }^{\circ} \mathrm{C}$} & & \multicolumn{2}{|l|}{ HHPTs } \\
\hline & So & WHC & So & WHC & & So & WHC \\
\hline Untreated A8 & $91.5 \pm 3.4^{\mathrm{a}}$ & $1.05 \pm 0.06^{\mathrm{b}}$ & $91.4 \pm 3.3^{\mathrm{a}}$ & $1.05 \pm 0.06^{b}$ & Untreated A8 & $91.4 \pm 3.3^{\mathrm{a}}$ & $1.05 \pm 0.06^{b}$ \\
\hline $5 \mathrm{~min}$ & $83.9 \pm 1.3^{\mathrm{b}}$ & $1.06 \pm 0.04^{\mathrm{b}}$ & $89.8 \pm 1.5^{\mathrm{a}}$ & $1.22 \pm 0.04^{\mathrm{a}}$ & $200 \mathrm{MPa}$ & $84.9 \pm 1.7^{\mathrm{c}}$ & $1.43 \pm 0.05^{\mathrm{a}}$ \\
\hline $10 \mathrm{~min}$ & $77.1 \pm 0.6^{\mathrm{c}}$ & $1.12 \pm 0.01^{\mathrm{b}}$ & $89.6 \pm 1.5^{\mathrm{a}}$ & $1.21 \pm 0.03^{\mathrm{a}}$ & $400 \mathrm{MPa}$ & $86.9 \pm 1.1^{\mathrm{bc}}$ & $1.14 \pm 0.03^{b}$ \\
\hline $30 \mathrm{~min}$ & $72.2 \pm 2.7^{\mathrm{d}}$ & $1.45 \pm 0.05^{\mathrm{a}}$ & $84.7 \pm 1.6^{\mathrm{b}}$ & $1.10 \pm 0.04^{b}$ & $600 \mathrm{MPa}$ & $90.6 \pm 1.0^{\mathrm{ab}}$ & $0.87 \pm 0.06^{\mathrm{c}}$ \\
\hline Untreated A10 & $93.6 \pm 3.6^{\mathrm{a}}$ & $0.95 \pm 0.01^{\mathrm{b}}$ & $93.6 \pm 3.6^{a}$ & $0.95 \pm 0.01^{\mathrm{c}}$ & Untreated A10 & $93.6 \pm 3.6^{\mathrm{a}}$ & $0.95 \pm 0.01^{\mathrm{d}}$ \\
\hline $5 \mathrm{~min}$ & $90.6 \pm 3.5^{\mathrm{a}}$ & $1.34 \pm 0.04^{\mathrm{b}}$ & $93.3 \pm 2.4^{\mathrm{a}}$ & $1.09 \pm 0.07^{b}$ & $200 \mathrm{MPa}$ & $87.5 \pm 2.4^{\mathrm{bc}}$ & $1.19 \pm 0.05^{c}$ \\
\hline $10 \mathrm{~min}$ & $88.2 \pm 3.6^{\mathrm{a}}$ & $1.36 \pm 0.08^{\mathrm{b}}$ & $93.8 \pm 2.3^{\mathrm{a}}$ & $1.10 \pm 0.02^{b}$ & $400 \mathrm{MPa}$ & $86.4 \pm 2.4^{\mathrm{c}}$ & $1.48 \pm 0.06^{\mathrm{b}}$ \\
\hline $30 \mathrm{~min}$ & $91.4 \pm 4.2^{\mathrm{a}}$ & $1.55 \pm 0.07^{\mathrm{a}}$ & $96.5 \pm 0.9^{a}$ & $1.49 \pm 0.07^{\mathrm{a}}$ & $600 \mathrm{MPa}$ & $92.1 \pm 1.5^{\mathrm{ab}}$ & $1.66 \pm 0.01^{\mathrm{a}}$ \\
\hline
\end{tabular}

The values are means \pm standard deviation. Different superscripts indicate significant differences $(\mathrm{p}<0.05)$ within columns for each treatment $\left(\mathrm{TT}\right.$ at $70{ }^{\circ} \mathrm{C}$, TT at $90{ }^{\circ} \mathrm{C}$ or $\mathrm{HHPTs}$ ). 
TT $70{ }^{\circ} \mathrm{C}$

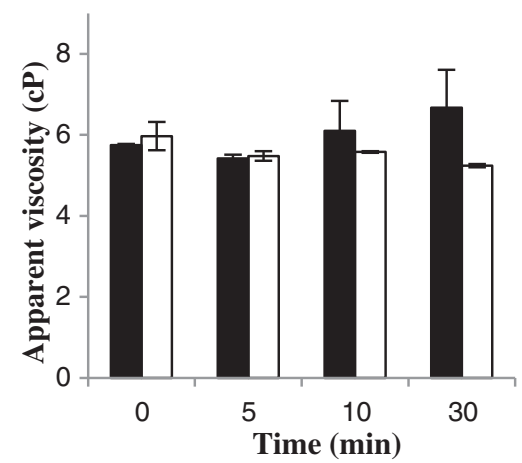

TT $90{ }^{\circ} \mathrm{C}$

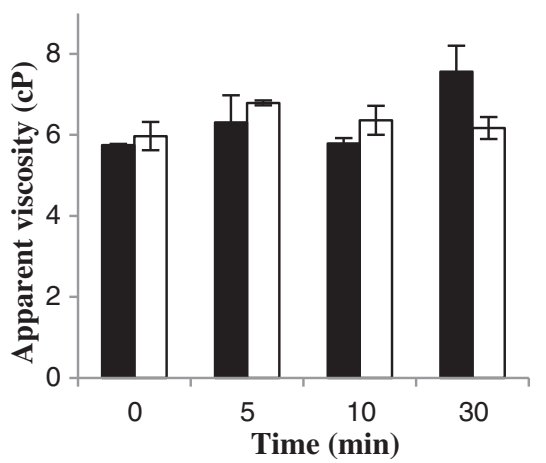

HHPT

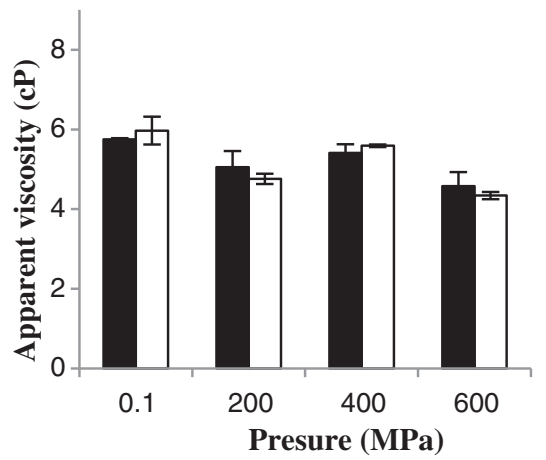

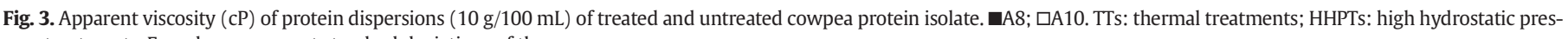
sure treatments. Error bars represent standard deviations of the means.

observations of Horax et al. (2004) and Khalid et al. (2012). The LGC of CPIs is lower than reported for pinto bean protein isolate $(16 \% \mathrm{w} / \mathrm{v})$ (Tan, Ngoh, \& Gan, 2014) and chickpea protein isolate $(14-18 \% w / v)$ (Kaur \& Singh, 2007), suggesting that CPIs have a better gelling ability than other legume protein isolates.

LGC of A 8 decreased to $10 \%$ after 10 or $30 \mathrm{~min}$ at $70^{\circ} \mathrm{C}$. Moreover, the firmness of A10 gels at $16 \%$ was enhanced by treatment at $70{ }^{\circ} \mathrm{C}$ (Table 4). This increase in firmness may be due to a high contribution of hydrophobic interactions in the gel, since the Ho of A10 was greatly increased after treatment at $70{ }^{\circ} \mathrm{C}$ (Table 1). On the other hand, TT at $90{ }^{\circ} \mathrm{C}$ had a negative effect on the gelling capacity; LGC of both A8 and A10 increased to $14 \%$ (Table 4). Ragab et al. (2004) informed that CPI cannot form a gel, but their isolate had been heated at $90{ }^{\circ} \mathrm{C}$ for $10 \mathrm{~min}$ in the process of isolation. The difference in the effect of both TT $\left(70\right.$ and $90^{\circ} \mathrm{C}$ ) could be due to differences in the structure of the aggregates formed in each of them; with the aggregates formed at $90{ }^{\circ} \mathrm{C}$ having a lower ability to realign and form the protein network. The better results were obtained with isolates treated at 200 and $400 \mathrm{MPa}$. LGC, decreased to $10 \%$ and firmness increased for A8 and A10. This result is opposite to that of Speroni, Jung and de Lamballerie (2010) who reported that heat-induced gelation of soybean proteins was not improved by HHPTs, indicating a differential effect of HHPTs that depends on the source of protein.

\section{Conclusion}

The CPI obtained by protein extraction at $\mathrm{pH} 10.0$ exhibited different physicochemical properties $\left(\lambda_{\max }\right.$, Ho and $\mathrm{T}_{\mathrm{d}}$ ) when compared to that

Table 4

Least gelation concentration (LGC \%) of treated and untreated A8 and A10 cowpea protein isolates.

\begin{tabular}{|c|c|c|c|c|c|c|c|c|c|c|}
\hline \multirow{2}{*}{$\begin{array}{l}\text { Sample } \\
\text { conc. } \\
(\% \mathrm{w} / \mathrm{v})\end{array}$} & \multirow[b]{2}{*}{ Untreated A8 } & \multicolumn{3}{|l|}{$70{ }^{\circ} \mathrm{C}$} & \multicolumn{3}{|c|}{$90{ }^{\circ} \mathrm{C}$} & \multicolumn{3}{|l|}{ HHPT } \\
\hline & & $5 \mathrm{~min}$ & $\begin{array}{l}10 \\
\min \end{array}$ & $\begin{array}{l}30 \\
\min \end{array}$ & $\begin{array}{l}5 \\
\min \end{array}$ & $\begin{array}{l}10 \\
\min \end{array}$ & $\begin{array}{l}30 \\
\text { min }\end{array}$ & $\begin{array}{l}200 \\
\mathrm{MPa}\end{array}$ & $\begin{array}{l}400 \\
\mathrm{MPa}\end{array}$ & $\begin{array}{l}600 \\
\mathrm{MPa}\end{array}$ \\
\hline 6 & - & - & - & - & - & - & - & - & - & - \\
\hline 8 & - & - & - & - & - & - & - & - & \pm & - \\
\hline 10 & \pm & \pm & + & + & - & - & - & + & + & \pm \\
\hline 12 & + & + & + & + & - & - & - & ++ & ++ & + \\
\hline 14 & ++ & ++ & ++ & ++ & + & + & + & ++ & ++ & ++ \\
\hline 16 & $\begin{array}{l}++ \\
\text { Untreated A10 }\end{array}$ & ++ & ++ & ++ & ++ & ++ & ++ & +++ & +++ & +++ \\
\hline 6 & - & - & - & - & - & - & - & - & - & - \\
\hline 8 & - & - & - & - & - & - & - & - & - & - \\
\hline 10 & \pm & \pm & \pm & \pm & - & - & - & + & + & \pm \\
\hline 12 & + & + & + & + & - & - & - & ++ & ++ & + \\
\hline 14 & ++ & ++ & ++ & ++ & ++ & ++ & ++ & ++ & ++ & ++ \\
\hline 16 & ++ & +++ & +++ & +++ & ++ & ++ & ++ & +++ & +++ & +++ \\
\hline
\end{tabular}

$(-)$ liquid, $( \pm)$ viscous, $(+)$ gel, $(++)$ firm gel and $(+++)$ very firm gel. obtained at pH 8.0. The polypeptidic composition was similar in both isolates, as assessed by SDS-PAGE, thus, these results indicate that the differences observed between both isolates were due to irreversible changes in the protein structure caused by the 60 min-exposure to $\mathrm{pH} 10.0$ during protein isolation.

The results presented herein demonstrate that TTs and HHPTs induced changes in the physicochemical and functional properties that were more drastic in A8 than in A10. These findings would be attributable to the fact that the structure/conformation of the $\mathrm{A} 10$ proteins had already been modified by the high extraction $\mathrm{pH}$. Even though both treatments have proved to modify the physicochemical and functional properties of proteins, the initial structure that they present influences the sensitivity to each treatment and thus the intensity of the changes. Notable differences between A8 and A10 in behaviors after treatments were found for So, Ho, fluorescence spectra and WHC.

Among the functional properties of proteins, solubility is of primary importance due to its influence on the other functional properties. In general, proteins used for functionality are required to have high So, our results indicate that treated and untreated CPIs may be obtained with high So in water (72-97\%), and could be used as a good protein source in beverages and/or functional ingredient. Our results suggest that CPIs may undergo drastic treatments (as those used for food conservation) and keep high So values.

The HHPTs was more efficient than the TT to modify certain functional properties, such as the LGC and the WHC. Moreover, this novel technology is less time-consuming than the conventional TT to obtain modified proteins that may be applied in desserts or other products where gel formation is important and/or as additives in other foodstuff where the improved WHC is exploited.

\section{Acknowledgments}

The authors acknowledge the financial support from ANPCyT (PICTBicentenario 2010-2341) and Universidad Nacional del Nordeste, Argentina (PI F003/11). The authors wish to thank Claudio Sanow from the Instituto de Tecnología de Alimentos, INTA, for his kind assistance during the use of the HHPT equipment.

\section{References}

AOAC, Official methods of analysis (1990). Association of official analytical chemists (15th ed.) (Arlington, Virginia. Method 920.87).

Avanza, M., Acevedo, B., Chaves, M., \& Añón, M. (2013). Nutritional and anti-nutritional components of four cowpea varieties under thermal treatments: Principal component analysis. Food Science and Technology, 51, 148-157.

Avanza, M. V., \& Añón, M. C. (2007). Effect of thermal treatment on the proteins of amaranth isolates. Journal of the Science of Food and Agriculture, 87, 616-623.

Avanza, M. V., Chaves, M. G., Acevedo, B. A., \& Añón, M. C. (2012). Functional properties and microstructure of cowpea cultivated in north-east Argentina. LWT-Food Science and Technology, 49, 123-130. 
Bera, M. B., \& Murkherjee, R. K. (1989). Solubility, emulsifying, and foaming properties of rice bran protein concentrates. Journal of Food Science, 54, 142-145.

Bernardino-Nicanor, A., Añón, M. C., Scilingo, A. A., \& Dávila-Ortiz, G. (2005). Functional properties of guava seed glutelins. Journal of Agricultural and Food Chemistry, 53, 3613-3617.

Cardamone, M., \& Puri, N. K. (1992). Spectrofluorimetric assessment of the surface hydrophobicity of proteins. Biochemistry Journal, 282, 589-593.

Chapleau, N., \& de Lamballerie-Anton, M. (2003). Improvement of emulsifying properties of lupin proteins by high pressure induced aggregation. Food Hydrocolloids, 17, 273-280.

Coffmann, C. W., \& García, V. V. (1977). Functional properties and amino acid content of a protein isolate from mung bean flour. Journal of Food Technology, 12, 473-484

Condés, M. C., Speroni, F., Mauri, A., \& Añón, M. C. (2012). Physicochemical and structural properties of amaranth protein isolates treated with high pressure. Innovative Food Science and Emerging Technologies, 14, 11-17.

Di Rienzo, J. A., Casanoves, F., Balzarini, M. G., Gonzalez, L., Tablada, M., \& Robledo, C. W. (2008). InfoStat, versión 2008. Córdoba, Argentina: FCA, Universidad Nacional de Córdoba.

Horax, R., Hettiarachchy, N. S., Chen, P., \& Jalaluddin, M. (2004). Preparation and characterization of protein isolate from cowpea (Vigna unguiculata L. Walp.). Journal of Food Science, 69, 114-118.

Kaur, M., \& Singh, S. (2007). Characterization of protein isolates from different Indian chickpea (Cicer arietinum L.) cultivars. Food Chemistry, 102, 366-374.

Khalid, I. I., Elhardallou, S. B., \& Elkhalifa, E. A. (2012). Composition and functional properties of cowpea (Vigna unguiculata L. Walp) flour and protein isolates. American Journal of Food Technology, 7, 113-122.

Kinsella, J. E., \& Melachouris, N. (1976). Functional properties of proteins in foods: A survey. C R C Critical Reviews in Food Science and Nutrition, 7(3), 219-280.

Laemmli, U. K. (1970). Cleavage of structural proteins during the assembly of head of bacteriophage T4. Nature, 227, 680-685.

Lakowicz, J. R. (1983). Principles of fluorescence spectroscopy (3rd edition ). New York: Springer Science Business Media.

Lowry, O. H., Rosebrough, N. J., Farr, A. L., \& Randall, R. J. (1951). Protein measurement with the folin phenol reagent. Journal of Biological Chemistry, 193, 265-267.

Ma, C. Y., \& Harwalkar, V. R. (1988). Study of thermal denaturation of oat globulin by ultraviolet and fluorescence spectrophotometry. Journal of Agricultural and Food Chemistry, 36, 155-160.

Manassero, C. A., Vaudagna, S. R., Añón, M. C., \& Speroni, F. (2015). High hydrostatic pressure improves protein solubility and dispersion stability of mineral-added soybean protein isolate. Food Hydrocolloids, 43, 629-635.

Mwasaru, M. A., Muhammad, K., Bakar, J., \& Che Man, Y. B. (1999). Effects of isolation technique and conditions on the extractability, physicochemical and functional properties of pigeon pea (Cajanus cajan) and cowpea (Vigna unguiculata) protein isolates: I. Physicochemical properties. Food Chemistry, 67, 435-443.

O'Reilly, C. E., Kelly, A. L., Murphy, P. M., \& Beresford, T. P. (2001). High-pressure treatment: Applications in cheese manufacture and ripening. Trends Food Science and Technology, 12, 51-59.
Permyakov, E. A. (1993). Luminescent spectroscopy of proteins (1st edition ). Florida: CRC Press, Inc (Chap. 3).

Petruccelli, S., \& Añón, M. C. (1994). Relationship between the method of obtention and the structural and functional properties of soy protein isolates. 1. Structural and hydration properties. Journal of Agriculture and Food Chemistry, 42, 2161-2169.

Petruccelli, S., \& Añón, M. C. (1995). Thermal aggregation of soy protein isolates. Journal of Agricultural and Food Chemistry, 43, 3035-3041.

Privalov, P. L. (1979). Stability of proteins: Small globular proteins. Advances in Protein Chemistry, 33, 117-241.

Qi, M., Hettiarachchy, N. S., \& Kalapathy, U. (1997). Solubility and emulsifying properties of soy protein isolates modified by pancreatin. Journal of Food Science, 62, 1110-1115

Ragab, D. M., Babiker, E. E., \& Eltinay, A. H. (2004). Fractionation, solubility and functional properties of cowpea (Vigna unguiculata) proteins as affected by $\mathrm{pH}$ and/or salt concentration. Food Chemistry, 84, 207-212.

Rangel, A., Domont, G. B., Pedrosa, C., \& Ferreira, S. T. (2003). Functional properties of purified vicilins from cowpea (Vigna unguiculata) and pea (Pisum sativum) and cowpea protein isolate. Journal of Agricultural and Food Chemistry, 51, 5792-5797.

Rivas, N. R., Dench, J. E., \& Caygill, J. C. (1981). Nitrogen extractability of sesame (Sesamurn indicum L.) seed and the preparation of two protein isolates. Journal of Food Agricultural, 32, 565-571.

Speroni, F., Añón, M. C., \& de Lamballerie, M. (2010). Effects of calcium and high pressure on soybean proteins: A calorimetric study. Food Research International, 43 1347-1355.

Speroni, F., Beaumal, V., de Lamballerie, M., Anton, M., Añón, M. C., \& Puppo, M. C. (2009). Gelation of soybean proteins induced by sequential high-pressure and thermal treatments. Food Hydrocolloids, 23, 1433-1442.

Speroni, F., Jung, S., \& de Lamballerie, M. (2010). Effects of calcium and pressure treatment on thermal gelation of soybean protein. Journal of Food Science, 75, 30-38.

Tan, E. -S., Ngoh, Y. -Y., \& Gan, C. -Y. (2014). A comparative study of physicochemical characteristics and functionalities of pinto bean protein isolate (PBPI) against the soybean protein isolate (SPI) after the extraction optimization. Food Chemistry, 152 447-455.

Tang, C. H., Sun, X., \& Yin, S. -W. (2009). Physicochemical, functional and structural properties of vicilin-rich protein isolates from three Phaseolus legumes: Effect of heat treatment. Food Hydrocolloids, 23, 1771-1778.

Tang, C. -H., \& Mab, C. -Y. (2009). Heat-induced modifications in the functional and structural properties of vicilin-rich protein isolate from kidney (Phaseolus vulgaris $L$.) bean. Food Chemistry, 115, 859-866.

Vasconcelos, I. M., Machado Maia, F. M., Farias, D. F., Cabral, C. C., Carvalho, A. F. U., de Acevedo Moreira, R., \& de Oliveira, J. T. A. (2010). Protein fractions, amino acid composition and antinutritional constituents of high-yielding cowpea cultivars. Journal of Food Composition and Analysis, 23, 54-60.

Yin, S. -W., Tang, C. -H., Wen, Q. -B., Yang, X. -Q., \& Li, L. (2008). Functional properties and in vitro trypsin digestibility of red kidney bean (Phaseolus vulgaris L.) protein isolate: Effect of high-pressure treatment. Food Chemistry, 110, 938-945. 